ORIGINAL ARTICLE

\title{
Postural analysis and repetitive motions of skidder operators in wood extraction
}

\author{
Análise postural e movimentos repetitivos de operadores de skidder em extração \\ de madeira
}

Anderson de Costa Paini ${ }^{1}$ (D), Eduardo da Silva Lopes $^{1}$ (D), Nilton César Fiedler ${ }^{2}$ (D), Amaury Paulo de Souza ${ }^{3}$ (D) , Carla Krulikowski Rodrigues ${ }^{1}$ (D) , Felipe Martins de Oliveira ${ }^{1}$ (b)

${ }^{1}$ Universidade Estadual do Centro-Oeste - UNICENTRO, Irati, PR, Brasil

${ }^{2}$ Universidade Federal do Espírito Santo - UFES, Jerônimo Monteiro, ES, Brasil

${ }^{3}$ Universidade Federal de Viçosa - UFV, Viçosa, MG, Brasil

\begin{abstract}
How to cite: Paini, A. C., Lopes, E. S., Fiedler, N. C., Souza, A. P., Rodrigues, C. K., \& Oliveira, F. M. (2020). Postural analysis and repetitive motions of skidder operators in wood extraction. Scientia Forestalis, 48(125), e3095.

https://doi.org/10.18671/scifor.v48n125.12
\end{abstract}

\begin{abstract}
Mechanized wood harvesting work may present risks to the operator's health. Thus, wood harvesting operations should be evaluated in relation to the postures adopted by operators and the repetitive motions of their upper limbs. The aim of this study was to analyze the postures and movements of upper limbs adopted by skidder operators in the wood extraction operation. The study was carried out in Pinus stands located in Paraná State, southern Brazil. The data were obtained by filming the skidder operators during the work shift. Then, typical postures were identified, and repetitive motions of upper limbs were quantified. Skidder operators have been exposed to harmful conditions to their health, due to the long period when they remained with postures deviated from the neutral line, as well as the trunk tilt and neck rotation, and absence of pauses to recover the upper limbs posture. For the adopted movements, wood extraction operation was classified as of average repeatability. Therefore, in the wood extraction, inadequate postures and repetitive motions are adopted by the skidder operators, for which ergonomic measures are needed to improve working conditions.
\end{abstract}

Keywords: Ergonomics; Forest harvest; Health; Mechanization.

\section{Resumo}

O trabalho de colheita mecanizada de madeira pode apresentar riscos à saúde do operador. Assim, as operações de colheita de madeira devem ser avaliadas em relação às posturas adotadas pelos operadores e aos movimentos repetitivos de seus membros superiores. O objetivo deste estudo foi analisar as posturas e movimentos dos membros superiores adotados pelos operadores de skidder na operação de extração de madeira. O estudo foi realizado em povoamentos de Pinus localizados no Estado do Paraná, Sul do Brasil. Os dados foram obtidos filmando os operadores do skidder durante o turno de trabalho. Então, posturas típicas foram identificadas, e os movimentos repetitivos de membros superiores foram quantificados. Os operadores de skidder têm sido expostos a condições prejudiciais à sua saúde, devido ao longo período em que permaneceram com posturas desviados da linha neutra, bem como à rotação do tronco e do pescoço, e ausência de pausas para recuperar a postura dos membros superiores. Para os movimentos adotados, a operação de extração de madeira foi classificada como repetibilidade média. Portanto, na extração de madeira, posturas inadequadas e movimentos repetitivos são adotados pelos operadores de skidder, nos quais medidas ergonômicas são necessárias para melhorar as condições de trabalho.

Palavras-chave: Ergonomia; Colheita florestal; Saúde; Mecanização.

Financial support: This study was financed in part by the Coordenação de Aperfeiçoamento de Pessoal de Nível Superior - Brasil (CAPES) - Finance Code 001. Conflict of interest: Nothing to declare.

Corresponding author: carlakr@gmail.com

Received: 2 October 2018.

Accepted: 4 June 2019

Editor: Francides Gomes da Silva Júnior.

(c) This is an Open Access article distributed under the terms of the Creative Commons Attribution License, which permits unrestricted use,

c) distribution, and reproduction in any medium, provided the original work is properly cited. 


\section{INTRODUCTION}

The Brazilian forestry sector has about 8 million hectares planted with Pinus and Eucalyptus species, with economic, social, and environmental importance that contribute to commercial exports, jobs, and natural forest protections. The intensification of forest mechanization, due to the high wood demand, provided several benefits, such as the increase of productivity and efficiency, quality of products and services, and reduction of costs (Machado et al., 2014). In the occupational aspect, technological advances promoted the transfer of physical effort to the forestry machines, in addition to significant improvements in working conditions (Silva et al., 2014). However, the use of these machines causes other ergonomics effects for the comfort, health, and safety of their operators.

In mechanized wood harvesting, the main ergonomic problems are the inadequate postures adopted by operators and the repetitive motions for long periods, due to the fast pace of work execution (Silva et al., 2009), in which the typical postures throughout the work shift are static and seated. These occupational activity characteristics can be considered highly fatiguing, since they require constant back and belly muscular activities, as well as body weight superimposed on the buttocks (lida \& Guimarães, 2016).

Another characteristic of mechanized wood harvesting work is the repetitive motions for upper limbs, confirmed by the Forestry Research Institute of Sweden (SkogForsk, 1999). By means of the forestry machines development and the inclusion of joysticks and levers, operational movements can cause Repetitive Strain Injuries (RSI) and Work-Related Musculoskeletal Disorders (WMSDs) (Phairah et al., 2016) that induce shoulder and neck pains in the operators (Murphy \& Oliver, 2011), with possible withdrawal from labor (Silva et al., 2013).

Thereby, ergonomics studies are necessary to identify possible risks related to typical body postures and repetitive motions adopted by forestry machine operators. In addition, ergonomic investigations support decision-making to improve working conditions, accident preventions, as well as comfort, safety, health, and life quality of forestry operators, focusing on the overall production system performance. For this, the aim of this study was to analyze the postures and movements of upper limbs adopted by skidder operators in the wood extraction operations of pine stands.

\section{MATERIAL AND METHOD}

This study was carried out in wood harvesting operational areas of a forestry company located in Paraná State, Brazil, between the coordinates $24^{\circ} 01^{\prime} 57^{\prime \prime}$ S and 50²7'30" W, with an average altitude of $776 \mathrm{~m}$. The region's climate is classified as Cfa, according to Köppen-Geiger, with annual averages of temperature equal to $19{ }^{\circ} \mathrm{C}$ and precipitation of $1,455 \mathrm{~mm}$ (Alvares et al., 2013).

The forest stands were composed of 16 years-old Pinus taeda L. in spacing of $3 \mathrm{~m} \times 2 \mathrm{~m}$ and under clear management regime, with average values of individual tree volume equal to $0.5 \mathrm{~m}^{3}$, mean annual increment of $27.3 \mathrm{~m}^{3} \mathrm{ha}^{-1}$ year-1, and volume production of $44.84 \mathrm{~m}^{3} \mathrm{ha}^{-1}$. The stands were managed to produce MDF (Medium Density Fiberboard) panel wood, PBO (Particle Board), laminate floors, and commercial logs.

A full-tree wood harvesting system composed by feller-buncher, skidder, and harvester machines was evaluated. In this system, feller-buncher cuts and bundles trees within the stands, while the skidder drags the tree bundles to the field edge, and the harvester processes the trees in different wood assortments according to consumer demands.

In the wood extraction with skidder, typical body postures and upper limbs movements were studied on three operators on the work shift (Table 1). The skidder had a nominal power of $194 \mathrm{~kW}$, operating weight of $21.4 \mathrm{Mg}$, tires with 6WD traction, clamshell with useful area of $1.95 \mathrm{~m}^{2}$, and 14,100 hours of use. 
Table 1. Characteristics of skidder operators in the wood extraction operation.

\begin{tabular}{lcc}
\hline \multicolumn{1}{c}{ Characteristics } & Average & Standard deviation \\
\hline Age (years) & 44.0 & \pm 8.0 \\
Stature (m) & 1.70 & \pm 0.05 \\
Body mass (kg) & 90.2 & \pm 7.4 \\
Right-handed (\%) & 100.0 & - \\
Machine experience (years) & 21.7 & \pm 11.1 \\
Current machine experience (years) & 6.3 & \pm 2.9 \\
\hline
\end{tabular}

This study was approved by the Research Ethics Committee (COMEP), in which the skidder operators received information about the research and the use of images and data, in compliance with the Resolution No. 466/2012 CNS/MS of the National Commission of Ethics in Research (CONEP) of Brazilian Ministry of Health (Brasil, 2012).

Typical postures and repetitive motions were recorded by filming the skidder operators on the work shift, in which two cameras equipped with a two-channel recording unit were installed inside the machine cabin (Figure 1). A camera was fixed inside the cabin to film the typical postures adopted by operators, while the other camera was turned out to film the extraction operation to identify the effective time of each operator's typical posture.

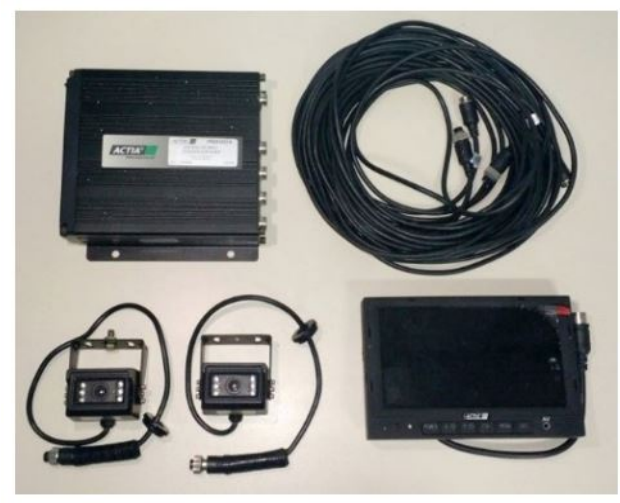

(a)

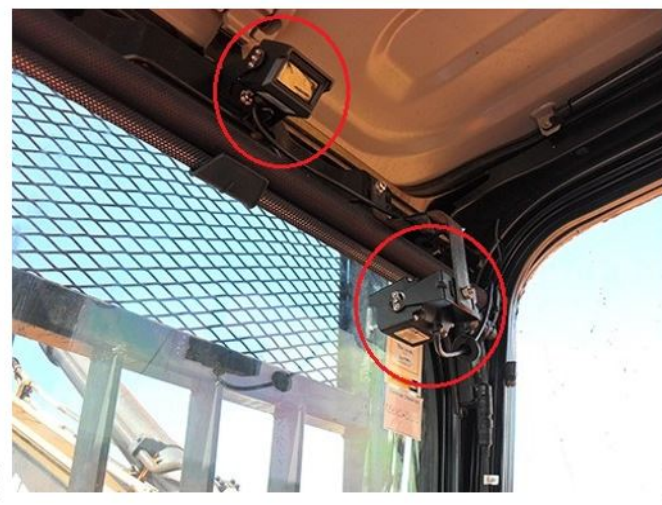

(b)

Figure 1. Set of cameras (a) and its location inside the skidder cabin (b) in the wood extraction operation.

Simultaneously, a time-motion study was carried out to determine the effective times of operating cycle elements: empty trip (EP), maneuvers and loading (ML), loaded trip (LT), and maneuver and unloading (MU). By means of the film data, typical postures adopted by operators were identified at each operational cycle element and analyzed by Rapid Upper-Limb Assessment (RULA) and Rapid Entire Body Assessment (REBA) methods.

RULA method (McAtamney \& Corlett, 1993) evaluates muscular works of upper limbs in a static way through the identification of angles in different body limbs, including repetitiveness and load handling analyzes. Thus, scores for each body segment of group $A$ (arms, forearms, wrists, and wrist rotation) and group B (neck, trunk, and legs) were obtained using specific tables, in which scores for the use of musculature and manipulated loads were added. For this, a final score was obtained to identify the action levels and verify the required intervention for each typical posture.

REBA method (Hignett \& McAtamney, 2000) is a semi-quantitative body evaluation that considers the static muscles, movement angulations, load handling, work repetitiveness, and handle quality. Posture scores were obtained with angulation specific tables to body group segments: A (trunk, neck, and legs) and B (arms, forearms, and wrists). The obtained scores increased with load handling, handle quality, and activity conditions (repetitiveness and maintenance of static postures) for composing the final score and action levels to verify the 
interventions needed for each posture. The possible final scores of REBA and RULA methods and respective results are shown in Table 2 .

Table 2. Possible postural results by REBA and RULA methods.

\begin{tabular}{cccl}
\hline Score & $\begin{array}{c}\text { Action } \\
\text { level }\end{array}$ & Risk & \multicolumn{1}{c}{ Action (providence) } \\
\hline REBA (Rapid Entire Body Assessment) & Insignificant & Acceptable posture; actions are not required \\
1 & 0 & Low & Actions may be required \\
2 or 3 & 1 & Medium & Actions are required \\
4 to 7 & 2 & High & Actions are quickly required \\
8 to 10 & 3 & Very high & Actions are immediately required \\
11 to 15 & 4 & $*$ & $\begin{array}{l}\text { Acceptable posture if not maintained or } \\
\text { repeated for long period. }\end{array}$ \\
RULA (Rapid Upper-Limb Assessment) & & $\begin{array}{l}\text { Investigations and possible work changes are } \\
\text { required. }\end{array}$ \\
1 or 2 & 1 & $*$ & $\begin{array}{l}\text { Investigations are required, as well as possible } \\
\text { quickly work changes. }\end{array}$ \\
3 or 4 & 2 & $*$ & $\begin{array}{l}\text { Investigations are required, as well as possible } \\
\text { immediately work changes. }\end{array}$ \\
5 or 6 & 3 & $*$ &
\end{tabular}

* It does not apply in this methodology. Source: McAtamney \& Corlett (1993); Hignett \& McAtamney (2000).

Repetitive motions performed by operators in each operational cycle element was quantified and converted to minute and work shift day, assuming an average operating efficiency equal to $80 \%$. In addition, Latko's scale, Silverstein's criterion, and Strain index (SI) methods were used to analyze RSI/WMSDs risks in upper limbs (Moore \& Garg, 1995; Silverstein et al., 1987; Latko et al., 1997).

Latko's scale (Latko et al., 1997) was used to analyze the repetitiveness level of activities based on the manual labor observation. This scale is numbered from 0 to 10 and contemplates movement dynamics and pause times in three hands activity levels: low - between 0 (hands stopped/inert most of time, without regular effort) and 1 (consistent, long visible pauses, very slow movements); medium - between 4 (constant slow motion, frequent small pauses) and 6 (constant movement/effort, non-frequent pauses); and high - between 8 (constant rapid movement or continuous exertion, non-frequent pauses) and 10 (constant rapid movement or continuous exertion, difficulty in maintaining/conserving).

Silverstein's criterion (Silverstein et al., 1987) considered the repeatability occurrence when identical movements were performed two to four times per minute, or when the operating cycle elements were performed in a time lower than thirty seconds. In addition, this criterion considers that the activity can be highly repetitive when the same work element is greater than $50 \%$ of the operating cycle.

SI (Moore \& Garg, 1995) is a semi-quantitative method to analyze the workstation and used to identify the RSI/WMSDs risks in distal upper limbs (hands), in which the $\mathrm{SI}$ is determined by multiplying the values obtained by the analyses of intensity, duration and frequency of effort, hand and wrist posture, and rhythm and duration of work. SI value less than 3 indicates the work is safe, with probable absence of WMSDs risks; between 3 and 5 means an uncertainty, with eventually recoverable WMSDs risks; between 5 and 7 shows some risk, in which the activity is associated with WMSDs; and above 7 indicates high WMSDs risk. 


\section{RESULTS AND DISCUSSION}

Skidder operating cycles showed an average time equal to 210 seconds, in which two typical operators' postures were observed, whose results of RULA and REBA methods are presented in Table 3.

Table 3. Typical postural of skidder operators in the wood extraction operation evaluated by RULA and REBA methods.

\begin{tabular}{|c|c|c|c|}
\hline \multirow{2}{*}{ Typical posture } & \multirow{2}{*}{$\begin{array}{c}\text { Posture } \\
\text { time } \\
\text { percentage }\end{array}$} & \multicolumn{2}{|c|}{ Evaluation method } \\
\hline & & RULA & REBA \\
\hline VIU & $56 \%$ & $\begin{array}{c}\text { S: } 4 \\
\text { L: } 2 \\
\text { D: Investigations and } \\
\text { possible work changes are } \\
\text { required }\end{array}$ & $\begin{array}{c}\text { S: } 6 \\
\text { L: } 2 \\
\text { R: Medium } \\
\text { D: Actions are required }\end{array}$ \\
\hline & $44 \%$ & $\begin{array}{c}\text { S: } 3 \\
\text { L: } 2 \\
\text { D: Investigations and } \\
\text { possible work changes are } \\
\text { required }\end{array}$ & $\begin{array}{c}\text { S: } 3 \\
\text { L: } 1 \\
\text { R: Low } \\
\text { D: Actions may be } \\
\text { required }\end{array}$ \\
\hline
\end{tabular}

ET is empty trip, $\mathrm{ML}$ is maneuvers and loading, $\mathrm{TL}$ is loaded trip, $\mathrm{MU}$ is maneuvers and unloading, $\mathrm{S}$ is score, $\mathrm{L}$ is action level, $\mathrm{R}$ is risk, and $\mathrm{D}$ is diagnosis.

The first typical posture was observed in $56 \%$ of the operational cycle times, with the activities: empty trip, maneuver and loading, and maneuver and unloading (Table 3). This posture was characterized by the trunk forward tilt between 20 to $60^{\circ}$, in which the extraction operation was turned to the machine's rear, with the operator's vision for the clamshell of tree bundle accumulation. For $44 \%$ of effective time, a second typical posture was observed in loaded trip (Table 3), in which the trunk tilt was not detected, due to the seat frontal position, and characterized by the operator's back propped on the machine seat back.

However, neck rotation was detected in all typical postures and caused by the seat with $100^{\circ}$ rotation, in which operators always remained in a diagonal position in relationship to the machine displacement. RULA postural evaluation indicated a similar action level between the two typical postures adopted by operators, but investigations and possible work changes are required. On the other hand, REBA method indicated a medium risk to operators' health with the first posture, while a low risk and actions may be required with the second posture.

By means of RULA and REBA methods, the typical postures showed the need for further investigations and possible changes in the workstation. These changes can be introduced by means of pauses and labor gymnastics, as well as training and awareness of operators on the correct postures. However, the use of machines adapted to the operators' bodily limitations should be considered to reduce the posture risks and repetitive motions imposed on them by the work operation.

Thus, RULA and REBA analyses provide a diagnosis of occupational function and can be used to select and develop machines with semi-automatic movements that are considered more ergonomic. The replacement of manually operated forest machines by semi- or fully-automated machines can mitigate ergonomics problems in the wood extraction by reducing movements and adopting adequate postures (Spinelli et al., 2017).

Repetitive motion analysis is presented in Figure 2, in which we observed the operators were exposed to moderate repetitive hand motions in the wood extraction operations, due to the use of machine's levers, especially in loaded and unloaded travels activities. 

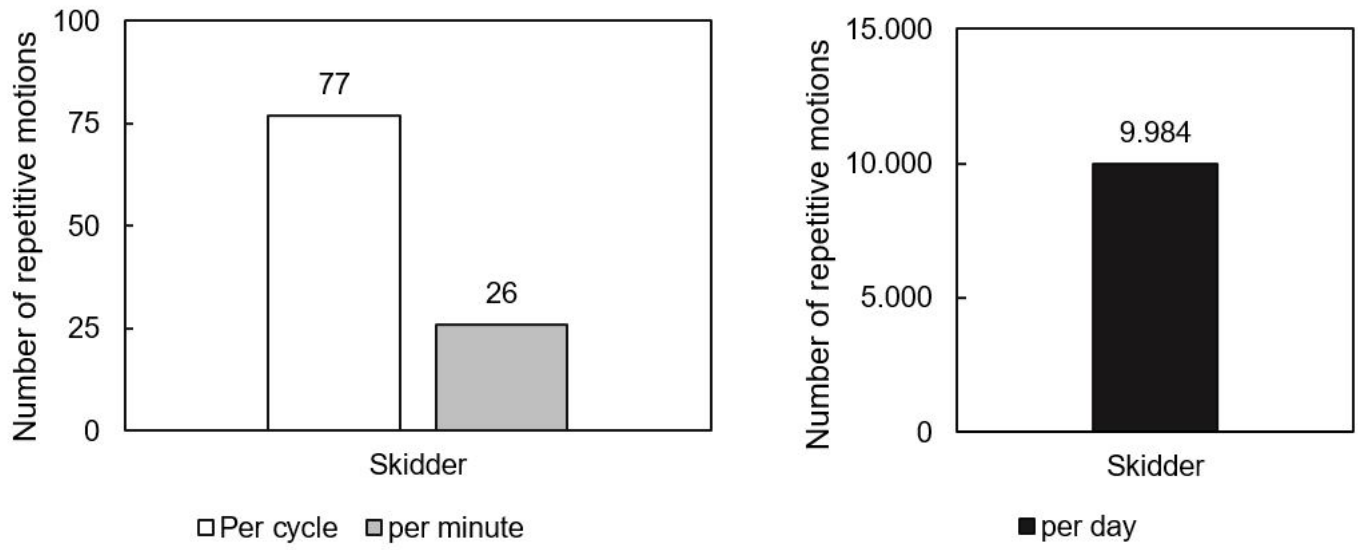

Figure 2. Repetitive motions by skidder operators in the wood extraction operation.

Repetitive motions in the wood extraction were verified in all evaluated methods (Table 4). Through Latko's scale (Latko et al., 1997), repetitiveness of movements performed by operators' hands was classified as score 6 . Thus, there were constant movements or efforts with non-frequent pauses that confirm the medium repetitive motions in the wood extraction operation.

Table 4. Evaluation of repetitive motions by skidder operators in the wood extraction operation.

\begin{tabular}{|c|c|}
\hline Method & Evaluation \\
\hline Latko's scale & $\begin{array}{c}S=6 \\
C=\text { constant movement or effort, and non-frequent pauses } \\
D=\text { medium repeatability }\end{array}$ \\
\hline Silverstein's criterion & $\begin{array}{l}C=\text { more than four repetitive motions per minute, and same operational } \\
\text { element covering more than } 50 \% \text { of the cycle } \\
\qquad D=\text { there is a repeatability }\end{array}$ \\
\hline Strain index (SI) & $\begin{array}{c}\mathrm{S}=9 \\
\mathrm{C}=\text { above } 7 \text { scores } \\
\mathrm{D}=\text { high risk of } \mathrm{RSI} / \mathrm{WMSD}\end{array}$ \\
\hline
\end{tabular}

$\mathrm{S}$ is score, $\mathrm{C}$ is characteristic, and $\mathrm{D}$ is diagnosis.

According to Silverstein's criterion, repeatability in wood extraction was observed, since it presented more than four repetitive motions per minute (Table 4). Besides that, we noted that a same operational element covered more than $50 \%$ of the operational cycle. In addition, the 9 scores obtained by $\mathrm{SI}$ method were higher than the value suggested by this method (7 scores), indicating a high risk of RSI/WMSD. This result showed that effort frequency was more than 20 per minute, with duration between 50 to $79 \%$ of the operational cycle, while the wrists and hands postures were classified as being reasonable and non-neutral.

In the wood extraction with skidder, the typical operators' postures were related to the operation and machine characteristics, especially by the chair with $100^{\circ}$ rotation around its axis, in which operators needed to rotate the neck and wrists by a high period to carry out the operation.

Thus, operators' health can be affected by injuries to the neck, arms, and cervical spine that are the main causes related to excessive periods in seated and static position, as well as the adoption of ergonomically inappropriate postures (Gerasimov \& Sokolov, 2014). These postures can damage muscles and joints, leading to strains on the body. Moreover, in the seated position, when the trunk and head are tilted, the neck and back are usually under 
stresses that can cause pain, as well as compromise the back by body rotation (Dul \& Weerdmeester, 2012).

The quantity of repetitive motions in this study can cause discomfort in hands and forearms of the operators. Repeatability is a significant risk when the worker performs more than 6,000 repetitions per shift work (Couto et al., 2007), while static and inadequate postures impair blood flow to muscles, resulting in lactic acid accumulation, fatigue, and pain. In this sense, tendons are not totally elastic structures, since when the movements are executed; they take a time until they return to the availability condition for a new muscular contraction (Couto et al., 2007). Thus, the absence of pauses between repetitive motions results in excessive use of the musculo-skeletal system, meaning a significant RSI/WMSDs risk.

Since the forest activities are cyclical, it is important to reduce the effects of repetitive motions on the human organism. As recommended ergonomics measures, recovery pauses can be used with labor gymnastics distributed during the work shift; implementation of training programs, aiming the operators' awareness on the adequate postures; and movements only necessary to carry out the activities. In addition, we suggested providing RSI/WMSD guidance by lectures and courses to contribute to improving comfort, well-being, safety, and health conditions of the forest operators.

\section{CONCLUSIONS}

Typical postures of skidder operators present ergonomics risks that can cause health damage and affect their performance at work, while the repetitive motions of hands and wrists, as well as the permanence in static positions for long period, are the main causes of kinesiological risks. Therefore, the evaluated skidder machine is not suitable for wood extraction operation, why we suggested it to be replaced by another one adapted to the operators and with semi-automated movements.

\section{ACKNOWLEDGEMENTS}

This study was financed in part by the Coordenação de Aperfeiçoamento de Pessoal de Nível Superior - Brasil (CAPES) - Finance Code 001.

\section{REFERENCES}

Alvares, C. A., Stape, J. L., Sentelhas, P. C., Gonçalves, J. L. M., \& Sparovek, G. (2013). Köppen's climate classification map for Brazil. Meteorologische Zeitschrift, 22(6), 711-728. http://dx.doi.org/10.1127/0941-2948/2013/0507.

Brasil. Ministério da Saúde. Secretaria de Vigilância em Saúde. Departamento de Vigilância em Saúde Ambiental e Saúde do Trabalhador. (2012). Dor relacionada ao trabalho: lesões por esforços repetitivos (LER): distúrbios osteomusculares relacionados ao trabalho (DORT). Brasília: Editora do Ministério da Saúde.

Couto, H. A., Nocoletti, S. J., \& Lech, O. (2007). Gerenciando a LER e os DORT, nos tempos atuais. Belo Horizonte: Ergo.

Dul, J., \& Weerdmeester, B. (2012). Ergonomia prática (Trad. Itiro lida, 3. ed.). São Paulo: Blucher.

Gerasimov, Y., \& Sokolov, A. (2014). Ergonomic evaluation and comparison of wood harvesting systems in Northwest Russia. Applied Ergonomics, 45(2), 318-338. PMid:23706292. http://dx.doi.org/10.1016/j.apergo.2013.04.018.

Hignett, S., \& McAtamney, L. (2000). Rapid entire body assessment (REBA). Applied Ergonomics, 31(2), 201-205. PMid:10711982. http://dx.doi.org/10.1016/S0003-6870(99)00039-3.

lida, I., \& Guimarães, L. B. M. (2016). Ergonomia: projeto e produção (3. ed.). São Paulo: Blucher.

Latko, W. A., Armstrong, T. J., Foulke, J. A., Herrin, G. D., Rabourn, R. A., \& Ulin, S. S. (1997). Development and evaluation of an observational method for assessing repetition in hand tasks. American Industrial Hygiene Association Journal, 58(4), 278-285. PMid:9115085.

http://dx.doi.org/10.1080/15428119791012793. 
Machado, C. C., Silva, E. M., Pereira, R. S., \& Castro, G. P. (2014). O setor florestal brasileiro e a colheita florestal. In C. C. Machado (Ed.), Colheita florestal (3. ed., pp. 15-45). Viçosa: UFV.

McAtamney, L., \& Corlett, E. N. (1993). RULA: a survey method for the investigation of world-related upper limb disorders. Applied Ergonomics, 24(2), 91-99. PMid:15676903. http://dx.doi.org/10.1016/0003-6870(93)90080-S.

Moore, J. S., \& Garg, A. (1995). The strain index: a proposed method to analyze jobs for risk of distal upper extremity disorders. American Industrial Hygiene Association Journal, 56(5), 443-458. PMid:7754975. http://dx.doi.org/10.1080/15428119591016863.

Murphy, T., \& Oliver, M. L. (2011). Evaluation of a dynamic armrest for hydraulic-actuation controller use. Applied Ergonomics, 42(5), 692-698. PMid:21208609. http://dx.doi.org/10.1016/j.apergo.2010.11.002.

Phairah, K., Brink, M., Chirwa, P., \& Todd, A. (2016). Operator work-related musculoskeletal disorders during forwarding operations in South Africa: an ergonomic assessment. Southern Forests, 78(1), 1 9. http://dx.doi.org/10.2989/20702620.2015.1126781.

Silva, E. P., Minette, L. J., Sanches, A. L. P., Souza, A. P., Silva, F. L., \& Mafra, S. C. T. (2014). Prevalência de sintomas osteomusculares em operadores de máquina de colheita florestal. Revista Árvore, 38(4), 739-745. http://dx.doi.org/10.1590/S0100-67622014000400017.

Silva, E. P., Minette, L. J., Souza, A. P., Baêta, F. C., Fernandes, H. C., Mafra, S. C. T., \& Vieira, H. A. N. F. (2009). Caracterização da saúde de trabalhadores florestais envolvidos na extração de madeira em regiões montanhosas. Revista Árvore, 33(6), 1169-1174. http://dx.doi.org/10.1590/S010067622009000600019.

Silva, E. P., Minette, L. J., Souza, A. P., Marçal, M. A., \& Sanches, A. L. P. (2013). Fatores organizacionais e psicossociais associados ao risco de LER/DORT em operadores de máquinas de colheita florestal. Revista Árvore, 37(5), 889-895. http://dx.doi.org/10.1590/S0100-67622013000500011.

Silverstein, B. A., Fine, L. J., \& Armstrong, T. J. (1987). Occupational factors and carpal tunnel syndrome. American Journal of Industrial Medicine, 11(3), 343-358. PMid:3578290. http://dx.doi.org/10.1002/ajim.4700110310.

SkogForsk. (1999). The forestry research institute of Sweden: ergonomic guidelines for forest machines. Uppsala: Swedish National Institute for Working Life.

Spinelli, R., Aminti, G., \& De Francesco, F. (2017). Postural risk assessment of mechanised firewood processing. Ergonomics, 60(3), 375-383. PMid:27215281. http://dx.doi.org/10.1080/00140139.2016.1172738.

Authors' contributions: ACP: conceptualization, data curation, formal analysis, methodology, project administration; ESL: funding acquisition, methodology, supervision; NCF and APS: supervision; CKR: validation, visualization, writing - original draft, writing - review \& editing, FMO: visualization, writing - original draft. 